\section{One or more Eemian interglacials?}

IN a recent paper (Nature 277, 189; 1979) we described the Fjosanger (interglacial) Stage in western Norway, and correlated it with deep sea oxygen isotope stage $5 \mathrm{e}$ and the Eemian of continental Europe. Bowen (News \& Views 277, 171; 1979) accepted the former correlation but criticised the latter, because he agrees with Kukla's proposal (Earth Sci. Rev. 13, 307, 1977) that the Eemian represents three different interglacials.

The vegetational development in different interglacials may have been so similar that a separation on palynological evidence is impossible. However, this is not necessarily so, and the crucial point in the present discussion is whether other interglacials repeated the distinct pollen sequence so far being considered as the criterion for the Eemian.

We fully agree with Bowen's statement that the deep sea oxygen isotope stratigraphy proves that the classical subdivisions of the Quaternary of Europe are incomplete. That is our challenge! However, an incomplete continental stratigraphy does not imply that all previously defined units are ambiguous.

Bowen claimed that Weigank (Geologie 21, Beiheft 77, 1; 1972) has described two Eemian interglacials in superposition in northern Germany. On the contrary, however, he stated that these two interglacials can be identified on the basis of their pollen stratigraphy, the younger being the Eemian, and the older the Rugenian (=Kap Arkona in Frenzel's classification).

Most important Bowen stated that Kukla (op. cit.) has demonstrated that the classical Eemian sites in Europe were deposited during three different interglacials. No doubt, Kukla made an extremely interesting analysis of the Quaternary stratigraphy of Elrope, but we cannot accept his evidence for more than one Eemian. Chiefly on the basis of geomorphological observations he postulated that the Saalian s.1. is composed of three distinct glacials, and he used Eemian sites for the presumptive interglacials so created. Most West German geologists (Duphorn et al. Eiszeitalter u. Gegenw. 23/24, 222; 1973) reject the existence of an interglacial within the Saalian s.1., but there are other more probable candidates (Rügen, Dömnitz/Wacken) to fill the milder intervals (see Weigank op. cit.; Erd Palaeogeogr., -clim., -ecol. 8, 129; 1970; Frenzel Eiszeitalter alter $u$. Gegenw. 23/24, 321; 1973; Menke \& Behre Eiszeitalter $u$. Gegenw. 23/24, 251; 1973; Cepek Ber. deutsch. Ges. geol. Wiss., A. Geol. Paläont. 12, 375; 1967) than the Eemian, even if Kukla's interpretation is correct.

The main evidence in support of our thesis that the typical Eemian pollen sequence represents only one interglacial can be summarised as follows, Many known Eemian sites are located inside the Weichselian ice border; all of them are situated below till or disturbed by ice. More than 100 Eemian sites are known outside the Weichselian ice border, and, as far as we know, not a single sequence is reported to be below till, or below another interglacial. However. many 'not Eemian interglacials' are known bslow till outside the Weichselian ice border.

We conclude that our present knowledge strongly suggests that the Eemian pollen sequence of Europe represents only one interglacial, which is the Last Interglacial.

\section{JAN MANGERUD}

EIVINd SonstegaARd

Hans-Pftter Sejrup

Department of Geology,

Allégt. 4l,

5014 Bergen-Universitetet,

Norway.

D. Q. BOWEN REPLIES: The points raised by Mangerud et al. are only valid in so far as the chronostratigraphy advocated by Kukla and others is incapable of direct validation at present. But the fact remains that the system they advocate and defend in the case of 'Eemian' is based on assemblage floras, a biofacies basis inherently unreliable as a result of its diachronous nature. Indeed by advocating that Woillard's (Quaternary Res. 9, 1; 1978) St Germain Interglacials, I and II, are time-equivalent to interstadials in the Netherlands and Denmark, also urged by Wijmstra (in Climatic Change (ed. Gribbin) Cambridge, 1978), they tacitly acknowledge the fragility of this bio- facies approach.

Discrimination of specific interglacials on the basis of either being covered by till or not in relation to postulated glacial limits is no improvement on 'count from the top' methods criticised by Kukla. In this way the current conventional wisdom, or model chronostratigraphic schema, is maintained. Data are not only interpreted on such model terms but are frequently acquired and systematised according to its pigeon-holed readymade classification-the "reinforcement syndrome' of the late Norman Watkins (Comments on Earth Sci. Geophys. 2, 36; 1971). In the case of Weigank's work the significant point relates to his demonstration that the foraminiferal faunas of the Eemian and Rügenian Interglacials show only minor differences.

The fact is that, according to present interpretation (Shackleton \& Opdyke Quaternary Res. 3, 39; 1973) and defining the base of the Middle Pleistocene at the Brunhes-Matuyama boundary (Butzer Quaternary Res. 4, 136; 1974), some eight interglacials occurred from that time to the present. It is pertinent to note that one of the UK working parties on International Geological Correlation Programme Project 24 is examining evidence to determine how many interglacials there have been since the Hoxnian. Conventionally there is only one-the Ipswichian (Eemian)! In the search for greater complexity in cor.unental records it is inevitable that some degree of data manipulation will occur initially because many of the basic facts regarding Pleistocene geology are still inadequately known. For too long has it been assumed that the Pleistocene geology of most formerly glaciated areas is known-perhaps it is, at least according to the terms of existing models. But in terms of modern lithostratigraphic standards (Hedberg Int. Stratigraphic Guide, New York, 1976) this work, with some notable exceptions (Willman \& Frye Illinois Geol. Surv. Bull. 94, 1970), has hardly commenced. In the meantime, other than by rare geochronometric dating, progress will inevitably include some manipulation born out of an expediency dealing with inadequate data.

\section{A hundred years ago}

WE need not insist on the extreme importance and interest of the exhibition which was opened last night at the Albert Hall, and for which extensive preparations have been making for some time. The public mind both in this country and abroad has been recently much agitated on the question of electric lighting, and, as might be expected, people are much confused among the many systems which have been brought forward, and even those who know something on the subject must find it difficult to make up their minds. Hence the importance of bringing together the various systems of electric lighting in such a way as to make comparison possible.

From Nature 20, 8 May, 39; 1879. 